\title{
Psychological study and religious value novel dear, imamku by mellyana
}

\author{
Liza Zahara $^{1}$, Missriani Missriani ${ }^{2}$, Yessi Fitriani ${ }^{2}$ \\ ${ }^{1}$ Madrasah Tsanawiyah Negeri 1 OKU, Indonesia \\ ${ }^{2}$ Universitas PGRI Palembang, Indonesia
}

\begin{tabular}{l}
\hline Article Info \\
\hline Article history: \\
Received Jul $12^{\text {th }}, 2021$ \\
Revised Aug $17^{\text {th }}, 2021$ \\
Accepted Aug $30^{\text {th }}, 2021$ \\
\hline
\end{tabular}

\section{Keyword:}

Literary psychology

Religious values

Novel

\begin{abstract}
This research is a qualitative one. The problem with this research is what is the psychological aspect of the characters in the novel Dear, Imamku by Mellyana? What are the religious values of the novel Dear, Imamku by Mellyana? The aim of this study is to describe the psychological aspects of religious characters and values in Mellyana's Dear, Imamku, novel. Analysis of the behavior and psychological symptoms of characters uses the psychological theory of personality developed by Sigmun Freud, combining the theory of personality dynamics, defense and conflict mechanisms, and the classification of emotions in the novel. The method used in this study was the method of qualitative content analysis. The data collection technique uses the analysis of document content. The data analysis technique used the technique of summarizing the text in steps; 1) data reduction, 2) data presentation, 3) conclusions. The results of this study show that there are psychological symptoms of characters in Mellyana's Dear, Imamku novel.
\end{abstract}

(C) 2021 The Authors. Published by IICET

This is an open access article under the CC BY-NC-SA license (https://creativecommons.org/licenses/by-nc-sa/4.0

\section{Corresponding Author:}

Zahara, L.,

Madrasah Tsanawiyah Negeri 1 OKU, Indonesia

Email: lifazaharason@gmail.com

\section{Introduction}

Everyday human life, which is full of problems, is often translated into literary activity, be it in prose, poetry or drama. Literature is not just narrative, but also creative art [1].

There are many problems or conflicts in everyday life, even in the media, both print and electronic, which cannot be disclosed [2]. This shows that literary works are not only fiction [3]. The conflict is, of course, related to the psychological aspects of the individual, which, if allowed to continue, will cause an individual to experience excessive anxiety, fear, and even stress, so that his life is useless. Feel unfair, feel ignored, so that most of these people end their lives. These conditions are frequently encountered in the novel Dear, Imamku by Mellyana [4].

Novel is a form of prose that tells the story of life and the lives of the characters from the beginning to the end [5]. Novels have more words than stories [6]. The elements of prose literature are theme, plot, setting. Characterisations, points of view and mandate [7]. Character and characterization cannot be separated to describe the character [8].

Humans as social beings need interaction as an effort to obtain information and as a means of communication. The interaction and process of human socialization are then shed into literary works with 
human objects as subjects with human psychological symptoms. Psychology of literature is the psychological element experienced by the characters in the story, which, in their study, requires psychoanalytic theory, that is, the theory of literary psychology. This theory was first coined by Sigmun Freud, who argued that there are three components to the structure of personality, namely the id (unconscious), the ego (unconscious, preconscious, conscious) and the super-ego (unconscious, pre-conscious, conscious) [9].

The id (das ex) is the most basic human personality system. Id is a basic desire that encourages people to act on the principle of enjoyment in the form of instincts and passions that do not recognize value. Id is an aspect of the personality "reservoir" of the psychic energy that drives the ego and the super-ego. The way the id works is linked to the principle of pleasure, which is to always seek pleasure and always avoid discomfort.

According to Endraswara [10] Das ich or ego is a personality system that acts as an individual's influence on the world of reality objects. Ego is a psychological and personality aspect that arises from an individual's need to relate to the real world. The principles of reality or reality adhere to the functioning of the ego. The ego can also be seen as an executive aspect of the personality, because it controls the path taken, chooses which needs can be met and how it can be fulfilled. In its function, the ego must often unite the contradictions between the id and the super ego. Super ego (das ueber ich) is a psychological aspect of a personality whose primary function is to determine whether something is right or wrong. In this way, individuals can act in accordance with good and bad moral values in society.

In addition, this novel can be used as a medium to convey good religious messages through its character as well as to deepen Islamic law [11]. Religious is the conduct of faith in God. The novel Dear, Imamku by Mellyana has been built full of religious values, especially Islam. The plot presented in this novel is very appropriate to the condition of society which is moving away from religious values.

The study in the novel Dear, Imamku by Mellyana is the application of the religious values of a person after he meets his priest who leads him to the religious teachings blessed by Allah, SWT. This is what the writer is trying to raise in the preparation of the thesis. The author is interested in studying the psychological values of characters that include id, ego, and super ego, and their relationship to the religious values of character behavior.

\section{Method}

The method used in this research is the Qualitative Content Analysis (AIK) method, which is a research method for the analysis of communications messages, whether written, oral or visual [12]. The technique for collecting data in this research is to use the analysis of documents. Documents are research data collection techniques that use written data sources for the collection of data. The steps of data collection are by reading the novel over and over again, noting what is being studied and interpreting it. This study uses a flow analysis technique called text summarization technique [11], i.e. analysis in three components, namely: 1) data reduction; 2) data presentation; and 3) conclusions drawn.

\section{Results and Discussions}

\section{Character personality analysis in Novel Dear, Imamku by Mellyana}

The analysis of the characters in the novel Dear, Imamku by Mellyana will be examined using Sigmund Freud's approach to literary psychology. The following will describe the main characters of Mellyana's Dear, Imamku novel:

\section{Alysa Salwa Safitri}

Alysa Salwa Safitri, known as Alysa, is the main character in Mellyana's Dear, Imamku. Alysa, an 18year-old girl in the twelfth grade of SMA, is the only child of Mila and Surya, a businessman. Because her parents are rich and she is the only child, Alysa automatically becomes a spoiled child, easily gets angry and cries when her wishes are not fulfilled. This can be seen from the quote below.

The girl moaned and then put the back of her mother's hand on her forehead, "It's not hot, Ma. It's already better. Later tonight will also recover. Really, Alysa isn't lying. Suwer. " She's showing the fingers forming a 'V.' "Papa is still in America. I'm not going to know if Alysa is sick, as long as you don't tell Dad. Ma, don't check on Alysa, huh? " Alysa's eyes spoiled her mother ... "[4] 
Alysa is not only ruined, she's also cowardly. Fear of the syringe, fear of the lightning, fear of what happened to his friend, which caused him to shake his soul violently. This can be seen from the quote below.

"Doc, don't get any injections! "Doc, watch out when you're injected! Don't do anything," he said, "Die, Doc, if you're injecting me! " [4].

"The... Suddenly, a lightning struck a tall tree on the side of the road, making the girl sitting in the back seat of the car tremble in fear..."[4].

Alysa's fear that really disturbed her soul was that she lost her best friend, Aisya. After the death of her best friend Aisya, Alysa's soul was badly shaken. Alysa's id fluctuated because she felt uncomfortable with her desire to die. Ego is trying to prevent him from having a long way to go in his life, still wanting to reveal who the killer of his best friend Aisya is. In this stage, the id and the ego are well controlled by the super ego. This statement is demonstrated by the following quotation.

$" . .$. His thoughts were only on the murder of Aisya. Alysa realizes that her life is still a long one. He must keep moving forward, struggling to uncover the perpetrator who killed Aisya.[4]

The feeling of loss kept making Alysa feel devastated. The id in Alysa realizes that she did something wrong by constantly crying over the departure of Alysa. His heart did not accept his friend's departure. His ego decided to find out who was the killer of his best friend. Alysa's super ego realized the desire of the id and the ego.

\section{Muhammad Haris Ibnu Sina}

Muhamad Haris Ibn Sina used to be called Haris, a young man who was tall and handsome. Haris works as a hermatologist and as a cardiologist. Haris is a young man who abides by religious law and is diligent in his worship. Her acquaintance with Alysa came from Alysa, who came for treatment and was injected with Haris, even though Alysa was very phobic with needles. As a result, Alysa was mad at Haris. This was the beginning of the conflict that colored the days of Haris. But with this incident, the cold and unromantic Haris falls in love with Alysa. Until the two of them finally got married. This statement is demonstrated by the following quotation.

"Haris wants to marry Alysa tonight because she doesn't want to be shackled in the well of sin for a long time. Because to think of people without ties is the same as to cheat on God [4]

\section{Aisya}

Aisya is a very good friend of Alysa's, caring, Korean drama lover to the point of memorizing all the actors in Drakor movies. This is an excerpt.

": Here, for you!" Aisya handed her the bottle that Alysa had taken.

"You really care, thank you, dear Aisya. I pray you can meet your oppa soon," Alysa laughed [4].

The id in Aisya wants her to be loved by all, but her ego is rebellious, if love cannot belong to one another and be forced. This is where the role of the super ego in responding to love in the form of goodness must continue. The expression of love was Aisya's last word, until she was finally killed because she was murdered. Alysa was shocked to hear the news. Her soul was violently shaken.

\section{Dina Maharani}

Dina is a friend of Alysa and Aisya's school, and she is also a patient of Dr. Haris. The character of Dina is very arrogant. This can be shown in the quotation below.

"He said arrogantly, 'Know, I'm Dina Maharani. The son of the owner of the foundation. I can't exercise that. I can't be tired of that. So, in this class, you have to enjoy me..." [4].

Dina seems to have a vengeful spirit, too. Dina's id doesn't accept seeing Alysa close to Haris. He felt hurt because he preferred Alysa to Haris. Dina's displeasure with Alysa is triggering the ego to control her. Because of that, he was trying to kill Alysa's best friend, and he was also trying to kill Alysa. The ego controls the id well in this position. The quotation below shows an illustration of the statement made by Dinah.

"If I die, you also have to die. And just so you know, Aisya died because of you. "

Unfortunately, Alysa smiled.

"Because of you, I killed Aisya. Because you've taken Doctor Haris out of me. "YOU MUST DIE!" [4]. 


\section{Lida}

Lida is the best friend of Haris, who also works as an obstetrician and works in the same place as Haris. Lida is two-sided. One side of his heart is kind, but the other side is an attitude that wants to kill someone. Lida's attitude towards Haris and Alysa is very good. This can be seen in the quotation below.

"Here, I bought a book. It's a translation of the book Qurrotul Uyun, it's about the early life of a household," said Lida, giving a large pile of books. "[4].

But Lida turns out to have evil intentions behind all her kindness. The id in her was not happy to accept Alysa and Haris. He's supposed to be the one who owns Haris completely, not Alysa. He wanted the death of Alysa, but through someone else's hand. Lida's ego started to get hold of it by going through other people. The other person is Dina, Alysa's school friend, and Naila, a staff member of the hospital where Haris works.

Id in Lida overcame all her senses. He couldn't even think that what he was doing was wrong. His ego also took control of his soul. What is desired must be obtained at all costs. The ego that arose was the desire to be with Haris, but unfortunately the costume was finally revealed. This is shown in the following quotation.

Alysa grinned dry. "It turns out you did it. You own those creepy eyes," he said. "And the killer was not Dina. Now he knows who's behind this problem. The mastermind is Lida. Friends of Haris [4].

6. f. Mr. X

Mr. X is a friend of Haris from Korea Mr.X is an expert in technology and has a special room to carry out his mission to complete investigations of various cases. It is through Mr. X that Haris tells the case of Aisya's death, Alysa's best friend, and asks Mr. X to reveal the case of Aisya's death, and to find out who is the mastermind behind Aisya's death. Mr. X's id wants his best friend Haris to be free from cases that terrorize his life. The id and ego positions have a strong energy in $\mathrm{Mr}$. X so that the super ego functions run as they should. This can be seen from the quote below.

Tit... Tit. Tit. The alarm in the glass room rang. Haris and Mr. X rushed in and checked the information.

"Naila put a bomb in the vicinity of Doctor Haris and the wedding hall of Alysa. From now on, the machines will start to defuse the bomb" [4].

\section{Figure of Psychological Studies}

\section{Afraid}

In the novel Dear, Imamku by Mellyana, the character Alysa had experienced the fear that had shaken her since the death of her friend Aisya. This can be seen in the quotation below.

"Alysa is away from school. Mama Alysa stayed at her son's house overnight because she was so worried about Alysa. Eating difficult, often on its own, and often crying. These days, that was all the girl's routine. His eyes are empty. "[4].

\section{Shame}

The shame is different from that of guilt. The appearance of shame, not related to guilt. This shame is shown by the character of Haris. This can be seen in the quotation below.

Alysa was looking at Haris. The man was looking confused. It doesn't work, you want to take a bowl. Want to have a glass, it doesn't work. Want to get away, sit down again... "[4] as well.

\section{Sadness}

Feeling sad or sorrowful, especially in conditions of grief, disappointment, despair, will make someone depressed. Sadness can be normal and only an indicator of illness if the feeling of sadness is excessive to the point of exhausting your energy and thoughts. In fact, sometimes prolonged sadness makes someone weak, easily influenced to do unwanted things. This is illustrated by the character Alysa, who is very sad at the departure of her best friend Aisya. See the quote below for more details. 
"Sincere. Easy to say, but hard to do, it's always been. This is the third day of Aisya's death. During those three days, Alysa was absent from school. Mama Alysa stayed overnight at her son's house because she was so worried about Alysa. Eating hard, often alone, and often crying. [4].

\section{Hatred}

Feelings of hatred are closely related to feelings of jealousy, anger, and jealousy. The sign that someone has feelings of hatred is that there is a desire or a desire to destroy an object that is the object of hatred. He will be satisfied when the object is destroyed. In the novel Dear, Imamku, by Mellyana, the feelings of hatred are clearly depicted in the characters Dina, Naila, and Lida. The following quote shows hatred for someone.

You're the usurper! And I hate you, man! "Dina's hand was tightly gripping Alysa's neck until she coughed, 'You must die! [4].

\section{Revenge}

Revenge is a negative habit that many people don't generally like. Often those negative qualities are hard to get rid of, even if they can potentially be suppressed or regulated if we can stress humility and honesty while living this life. This vengeful aspect is demonstrated by the character Lida in Mellyana's Dear, Imamku, who is not content with the union of Haris and Alysa. This can be seen in the quotation below.

"He found a portrait of Nail's eyeball murderer. And Dina wasn't the murderer. Now he knows who's behind the issue. Lida is the mastermind. It's Mates of Haris [4].

\section{Love.}

The feeling of love is an experience of intense desire, passion and personal attraction. Typicall this feeling of affection evolves and progresses over time. Don't know where and where it came from. In passion, etched with gratitude, a feeling of needing to protect and protect, and even of not wanting to be separated from it. Feelings of love are well reflected in the characters Haris and Alysa. The following quotation indicates the affection between Haris and Alysa.

"This place is gorgeous, but it feels hollow without you by my side. I miss you a lot, My Lovely. "It's like his passion for Alysa. It doesn't take any chances there. He cares only to love, love, and love Alysa because of Allah [4].

\section{Indictment of Guilt}

In the case of remorse, a person continues to feel guilty by holding him in himself, he's generally good, but he's a bad person. In Dear Imamku, Mellyana, the character Alysa feels remorse. Feelings of remorse against Haris who did not acknowledge Haris' shortcomings. The argument of Haris can be found in the following quotation.

"... Her cries are turning hysteric. He tightly hugged the journal. Haris' writing in Alysa's diary became a rebuke that struck the girl hard. Guilt had reached the hollow of his chest. Why can't he consider the loss of Haris? In reality, this man still admits his shortcomings"[4].

\section{Religious beliefs in the novel Dear Imamku by Mellyana}

\section{Faithful service of God (prayer)}

In the novel Dear, Imamku by Mellyana, an individual who is vigilant in prayer, both fardhu and sunnah, is Haris. The form of self-giving to His Lord is embodied in prayer. Worshiping prostrate to Him who rules human life. This can be seen in the quotation below

"He tilted to the side, looking at Haris, who was praying. After he had prayed, Haris grinned at Alysa. "[4].

"The... Don't you pray to Duha?"

"This is just about wudu." Haris replied [4].

\section{Reading the Quran}

Another type of religious significance is the recitation of the sacred verses of the Qur'an. The Qur'an is a holy text of Muslims that retains its originality and integrity, and is worth worshiping as well. This is mirrored in the figure of Haris in the following quotation. 
"He took a copy of the Qur'an and sat on the sofa. Five seconds later, the bounce of the surah AlFatihah was heard, followed by the surah Al-Waqi'ah. One of the surahs he dedicates to be read every day is Al-Waqi'ah [4].

\section{Always say hello}

In our everyday encounters, we always hear or say, "Assalamu'alaikum warahmatullahi wabarakatuh." This is a greeting between one Muslim and the other when we meet. The habit of greeting is specifically depicted in the novel Dear, My Imam by Mellyana in the figure of Haris, as seen in the following quotation.

As usual, Haris stared at Alysa from the middle of the mirror with the usual flat expression. "Assalamu'alaikum ...." "wa'alaikumussalam ...," Alysa replied [4].

\section{Clever Gratitude}

Gratitude for what the maker offers is going to make us feel happier. Expressions of gratitude are seen from the figure of Alysa, who is astounded by natural phenomena. This can be seen from the quote below.

"The.... This effect can be caused by the moon, by the sun, or by light sources on earth. The Light Pillar normally occurs in cold areas with temperatures below $10^{\circ} \mathrm{C}$. "Theoretically, Haris explained.

Alysa grinned, "Masya Allah," and glorified with sparkling eyes.

\section{Covering the Genitals}

Covering the aura is one of the recommendations of Islam. Similarly, what the figure of Haris had done to his wife, Alysa, to wear the hijab. This is seen in the quote below.

"Hijab has nothing to do with the same morality, Alysa. Don't be like a kid like that: Haris' longest sentence used to snap it. [4].

\section{Pray faithfully.}

Any human being has his or her beliefs or dreams. But often, through our best intentions, what we strive to is not accomplished. Let us then follow the endeavor by praying a great deal to Heaven. This prayer habit is represented in the figure of Haris in the following quotation from the novel Dear Imamku by Mellyana.

God the Almighty transforms the heart, sets the heart of Alysa to always love You and the servant because of You, the prayer of Haris in the heart" [4].

\section{Forgiveness}

Forgiveness is a praiseworthy attitude that is strongly recommended by religious beliefs. Forgiving the wrong committed by an individual is an act of worship that will later become a compensation field in the hereafter. Alysa and Haris also share this forgiving attitude. Here's a quote.

"I'm sorry, Sa, if I'm not biased to be a good friend for you."

Alysa smiled, "Lo why really? If you do it, from the beginning you have forgiven me ....

\section{Conclusions}

The conclusion of this analysis is in the context of a psychological examination, including the id, which is the key component of the identity that has been present since birth. The id is motivated by the concept of satisfaction, which aims to meet both desires and needs, if it is not satisfied, it will induce anxiety and tension..

\section{References}

Kosasi. (2017). Apresiasi Sastra Indonesia [Appreciation of Indonesian Literature]. Jakarta: Nobel Edumedia. Emzir \& Rahman, S. (2016). Teori dan pengajaran Sastra [Literature theory and teaching]. Jakarta: PT Raja Grafindo Persada.

Ratna, N. K. (2011). Teori, Metode dan Teknik Penelitian Sastra [Theory, Methods and Techniques of Literary Research]. Yogyakarta Pustaka Pelajar. 
Mellyana. (2018). Dear, Imamku. Jakarta: Andalusia.

Aminuddin. (2012). Apresiasi Karya Sastra [Appreciation of Indonesian Literature]. Bandung: Sinar Baru Algensindo.

Tarigan, H .G. (2012). Prinsip-Prinsip Sastra [Literary Principles]. Bandung: Angkasa.

Nurgiyantoro, B. (2010). Penilaian Pembelajaran Bahasa [Assessment of Language Learning]. 'Yogyakarta: BPFE Yogyakarta.

Wibowo, H. \& Hendriyani, I. (2018). Materi Umum Bahasa Indonesia SMP [Junior High School Indonesian Language General Materials]. Depok: Putri Cipta.

Minderop, A. (2010). Psikologi Sastra (Literature Psychology]. Jakarta: Yayasan Obor Indonesia.

Endraswara, S. (2013). Metode Penelitian Psikologi Sastra [Literary Psychology Research Methods]. Yogyakarta: Media Presindo.

Sriwilujeng, D. (2017). Panduan Implementasi Penguatan Pendidikan Karakter [Guidelines for the Implementation of Strengthening Character Education]. Jakarta: Erlangga.

Supratiknya, A. (2015). Metodologi Penelitian Kuantitatif \& Kualitatif dalam Psikologi [Quantitative \& Qualitative Research Methodologies in Psychology]. Yogyakarta: Universitas Sanata Dharma. 